\title{
Patiëntenvoorlichting
}

\section{PV 35. Mediane rhomboïde glossitis}

Mediane rhomboïde glossitis is een aanduiding voor een vaak, maar niet altijd, in het midden van de tong gelegen rode, vlakke maar soms ook iets hobbelige plek. Deze plek kan enigszins ruitvormig (=rhomboïd) zijn. De afwijking lijkt te berusten op een plaatselijke ontsteking (-itis) van de tong (=glossa), vandaar de term glossitis. In sommige gevallen lijkt de afwijking te worden veroorzaakt door schimmels, die oppervlakkig het slijmvlies binnendringen. Soms leidt dit tot klachten van irritatie. Bevorderende factoren zijn roken en het gebruik van hormoonbevattende spray, bij voorbeeld bij astmatische klachten. In sommige gevallen is er geen oorzaak aantoonbaar.

Mediane rhomboïde glossitis komt vooral voor bij volwassenen. De diagnose kan meestal met het blote oog worden gesteld, maar een enkele maal is er behoefte aan nader onderzoek in de vorm van weefselonderzoek door de patholoog. Wanneer er geen klachten zijn, is er geen dwingende reden om tot behandeling met een antischimmelmiddel in de vorm van een mondzalf of mondspoeling over te gaan. Uiteraard is stoppen met roken, indien aan de orde, belangrijk. De afwijking zal in principe levenslang aanwezig blijven. Er is geen sprake van besmettelijkheid en de afwijking leidt ook niet tot het ontstaan van tongkanker.

\section{Wat kunt u zelf doen?}

Bij mediane rhomboïde glossitis is het belangrijk te stoppen met roken. Bij het gebruik van hormoonbevattende spray is het belangrijk om, conform het advies daarover in de bijsluiter, na het sprayen de mond enkele minuten goed te spoelen met water.
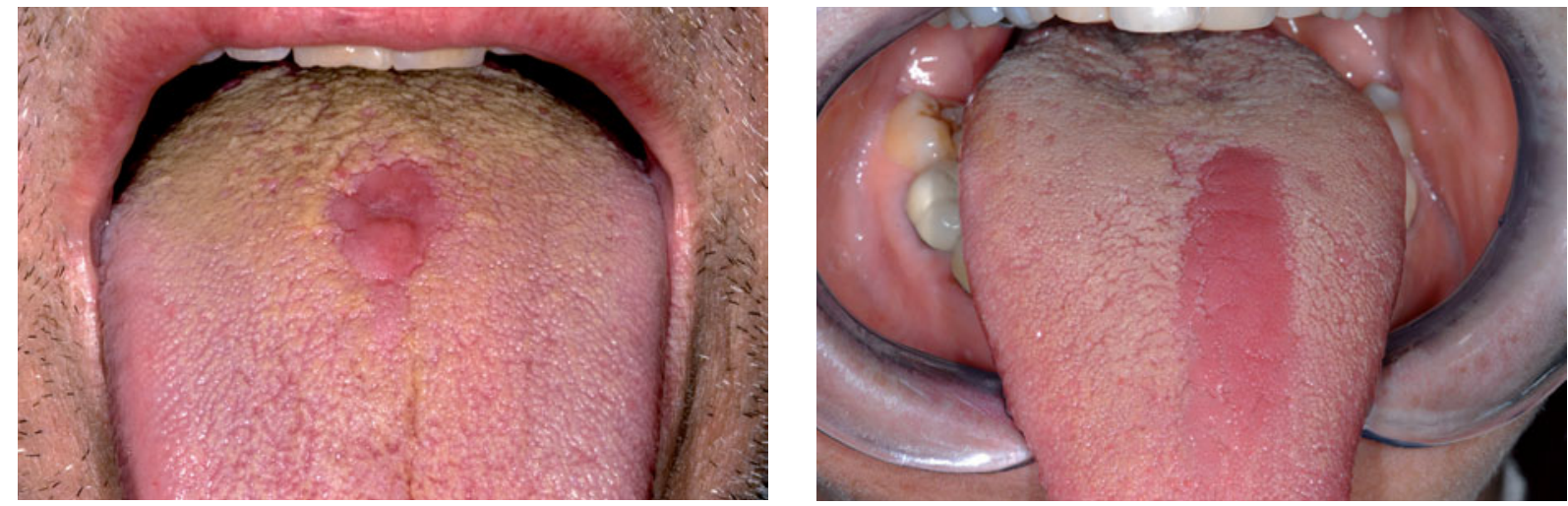